\title{
Study the Genetic Variations Related to the Resistance of Heavy Metals Toxicity in Some Rice Genotypes Using RAPD Markers
}

\author{
S. A. A. Heiba ${ }^{1}$, A.A.El-Mouhamady ${ }^{1}$, Sara E. I. Eldessouky ${ }^{1}$, \\ Hoda B. M. Ali ${ }^{1}$ and T.A. Elewa ${ }^{2}$ \\ ${ }^{1}$ Department of Genetics and Cytology, Division of Genetic Engineering and Biotechnology, \\ National Research Centre, Dokki, Giza, Egypt \\ ${ }^{2}$ Field crops Research Dept., Agriculture and Biological Division, National Research Center, \\ Dokki, Giza, Egypt \\ *Corresponding author
}

\section{A B S T R A C T}

\section{Keywords}

Rice,

Half Diallel,

GCA,

SCA,

Heterosis,

Heavy metals

and RAPD

markers

Article Info

Accepted:

09 December 2015

Available Online:

10 January 2016
Six genotypes of rice highly tolerance for salinity and drought, while different in terms of response for resistance of heavy metals namely, $(\mathrm{P} 1=$ Sakha105), $(\mathrm{P} 2=$ Sakha 106),(P3= Giza 179), (P4= GZ842312-9-4-5-1),(P5= IR 75) and $(\mathrm{P} 6=\mathrm{IR}$ 60 ), were used in this study through hybridization among them using half diallel analysis to check their ability to reduce the accumulation of heavy metals in leaves. Some characters were studied in this experiment, e.g. heading date, Plant height, Number of filled grains/panicle, 1000-grain weight, grain yield per plant, Cadmium , Copper, Cobalt, and Zinc Contents, in addition to genetic parameters, such as combining ability effects and heterosis over better -parent which were the measurements of genetic calculated through genetically and statistical analysis. RAPD-PCR using seven primers has been performed to investigate the phylogenetic relationships among the six parents and their four hybrids (The highest and lowest two values for the performance of characters) namely, H1 (Sakha 105 X Sakha 106), H2 (Sakha 106 X IR75), H3 (Giza 179 X IR60) and H4 (GZ842312-9-4-5-1X IR 75) respectively. It could be concluded that H4 was the high hybrid and the four parents, P1, P2, P3 and P5 seems to be the most suitable for it. Through the final review of the results for the averages observed that the following genotypes,(Sakha 106), (GZ842312-9-4-5-1),(IR 75),( (Giza 179 X IR 60) and (GZ842312-9-4-5-1X IR 75) were more resistant to the accumulation of such heavy metals and gave carries a high tolerance of the plants of rice that would increasing the resistance of the risks of the environmental stresses as well as reducing the toxicity.

\section{Introduction}

Rice is one of the most important crops that provide food for about half of the world population. In areas such as Asia, Africa and Latin America where the demand for rice is 
a top priority, the population is expected to increase 1.5-fold by 2025 (Sasaki, 1999 and 2002).Egypt is one of the few countries which produce high yielding rice varieties. From the commercial point of view, If we look at severity level of heavy metals higher in the juice cellular exchange we will find a crop and its components impact and also its impact on the molecular level and of course, produces all of this from the excessive use of fertilizers, fungicides and insecticides as well as the level of these elements in the Egyptian soil. The development of DNA marker technology has provided an efficient tool to facilitate plant genetic resource conservation and management. Compared to morphological analysis, molecular markers can reveal differences among accessions at DNA level. They represent an opportunity to provide information on the variation that exists in a particular species within a local region as well as among different countries. They serve as a valuable guide for effective collection and use of genetic resources too. Molecular markers provide a good information that helps in deciding the distinctiveness of species and their ranking according to the number of close relatives and phylogenetic position (Rahman et al., 2007). DNA fingerprinting is a useful tool for varietal protection to prove ownership or derivation of plant lines. Moreover, the analysis of genetic diversity and relatedness between or within different species, populations and individuals is a prerequisite towards effective utilization and protection of plant genetic resources (Weising et al., 1995).Comparing with morphological and biochemical markers which are not much consistent for diversity analysis because of the impression of environmental factors. For reliable and efficient analysis of genetic variation in the germplasm and to elucidate the intra- and inter-specific relationships, the use of molecular markers is prerequisite (Rabbani et al., 2010).Application of molecular markers enhances the efficiency of traditional plant breeding by indirect selection through molecular markers linked to both simple and quantitative traits of interest as these are not influenced by the environment and can be scored at all stages of plant growth (Gupta et al., 1999). After listing all of the above note that the aim of this study are based on determine the molecular genetic differences through study heterosis over better-parent, general and specific combining ability effects for some traits related to resistance of heavy matals in addition to compare between the promising genotypes using RAPD markers to know the effect of heavy metals on the yield and its components in rice under Egyptian soil conditions without any addition to the heavy industrial components and clarify the real selecting elite genotypes resulting from the mating of parents and the most resistance for accumulation of heavy metals, the highest yielding and determine the genetic differences in molecular level using detect fingerprinting for each genotype.

\section{Materials and Methods}

Six genotypes of rice revealed different response for the resistance to heavy metals were used as parents for the further crossing, $(\mathrm{P} 1=$ Sakha 105), $(\mathrm{P} 2=$ Sakha 106),$(\mathrm{P} 3=$ Giza 179), $(\mathrm{P} 4=\mathrm{GZ842312-9-4-5-1)},(\mathrm{P} 5=$ IR 75) and (P6 = IR 60), which were grown in three replicates for each genotype with ten days interval in order to overcome the differences in flowering time between parents to make hybridization in season 2013 in the farm of Agga center, Mansoura city, Dakahlia Governorate, which knowing that this farm is a farm scientific research and supported and approved by agronomy department, Faculty of Agriculture, Mansoura University,

All genotypes "parents and their crosses" 
were grown in a randomized complete Block design with three replicates for each genotype in season 2014 in the research region aforementioned without any external additions of heavy metals. Heading date, Plant height, number of filled grains/panicle, 1000-grain weight, Grain yield per plant, Cadmium, Copper, Cobalt and Zinc Contents were the studied traits and data obtained were analyzed by half diallel analysis using Griffing (1956), model 1, method 2.

This region is famous of high proportion of heavy metals and this information has been confirmed after the chemical analysis of soil as follows:-

30 soil samples were taken from the depth of $60 \mathrm{~cm}$ for the experimental field before conducting the agriculture to determine the level of heavy metals in the soil in season 2014 and the means of (Cadmium, Copper, Cobalt, and Zinc Contents) were (6.44,10.82,5.14 and $48.15 \mathrm{mg} \quad \mathrm{kg}-1)$ respectively, in addition to determine (EC $(\mathrm{dS} / \mathrm{m}), \mathrm{pH}$ (1:2.5), TDS mg/liter (ppm), $\mathrm{Ca}^{++}, \mathrm{Mg}^{++}, \mathrm{Na}^{+}, \mathrm{K}^{+}, \mathrm{CO}^{--}, \mathrm{HCO}^{-}, \mathrm{Cl}^{-}$and $\mathrm{SO}^{-}$where the values were $(1.76,7.15,940.67,4.3,3.22,12.26,0.32,0.06,5$ $.76,14.55$ and2.04),respectively.Vegetative samples were taken as well as to measure the levels of the four heavy metals in the leaves of each genotype for the three replicates at the age of 60 days in the growing plants and the averages were measured accounted.

\section{Studied Traits}

Thirty plants were taken for each genotype randomly from each replicate to determine heading date, Plant height, Number of filled grains per panicle, 1000-grain weight, grain yield per plant in addition to determine the following heavy metals, (Cadmium, Copper,
Cobalt and Zinc Contents) according for the method of Chander et al., (2001a and 2001b) and modified by Dospatlive L., et al., 2012.

\section{Statistical Analysis}

If the genotypes mean squares were found to be significant there were a need toproceed for further analysis; i.e., Griffing (1956) model 1, method 2,Heterosis over better parent and combining ability effects in half diallel analysis were determined by Wyanne et al., (1970).

\section{Molecular Studies}

Molecular studies aimed to determine the phylogenetic tree and relationships between different varieties of rice in steps:

\section{DNA Extraction and RAPD Analysis}

DNA was extracted from ten genotypes of rice varieties by Bio basic kits protocol.

\section{PCR- Amplification of RAPD}

Amplification reaction was carried out in $25 \mu \mathrm{l}$ reaction mixture contained $2 \mu \mathrm{l}$ of genomic DNA, $3 \mu \mathrm{l}$ of the primer, $2.5 \mu \mathrm{l}$ of 10X Taq DNA polymerase reaction buffer, 1.5 units of Taq DNA polymerase and 200 $\mathrm{mm}$ of each dNTPs. The following PCR program was used in a DNA Thermocycler (PTC-100 PCR version 9.0-USA). Initial denaturation at $94^{\circ} \mathrm{C}$ for $5 \mathrm{~min}$, followed by 35 cycles of $94^{\circ} \mathrm{C}$ for $30 \mathrm{~s}, 42^{\circ} \mathrm{C}$ for $90 \mathrm{sec}$. for annealing temperature, $72^{\circ} \mathrm{C}$ for $90 \mathrm{Sec}$. and final extension at $72^{\circ} \mathrm{C}$ for $2 \mathrm{~min}$. Products by RAPD- PCR were separated on $1.5 \%$ agarose gels in $1 \mathrm{X}$ TAE buffer and detected by staining with ethidium bromide according to Sambrook et al., (1989). DNA ladder 100bp was used and PCR products were visualized by UV-transilluminator and 
photographed by gel documentation system, Biometra - Bio Documentations, the amplified bands were scored as (1) for presence and (0) for the absence of all studied rice according to gel analyzer protocol.

\section{RAPD Analysis}

A set of seven random 10-mer primers, (Table 2) was used in the detection of polymorphism among ten genotypes of rice. These primers were synthesized at RAPDPCR and carried out according to the procedure given by Williams et al., (1990) with minor modifications.

The RAPD analysis was made for ten genotypes of rice (six parents and four crosses),where, (P1)(Sakha105),(P2)(Sakha 106),(P3)(Giza 179),(P4) (GZ842312-9-4-51),(P5) (IR 75) and (P6) (IR 60), in addition to low crosses,H1(Sakha $105 \mathrm{X}$ Sakha 106), H2(Sakha 106 X IR75) and high crosses, H3(Giza 179 X IR60) and H4 (GZ842312-94-5-1X IR 75) respectively, based on the results of half diallel analysis, heterosis over better-parent and combining ability effects.

\section{Results and Discussion}

\section{Mean Performance}

Through the presentation of the most important results in Table (3), we notice that there is considerable variation in the response of parents and their F1 (crosses) for heavy metals and this were clear from the display the table of means performance.

The genotypes., (Sakha 106),(GZ842312-94-5-1), (IR 75) and the crosses (Sakha 105) X (GZ842312-9-4-5-1), (Giza 179) X (GZ842312-9-4-5-1),(Giza 179 X IR 60), (GZ842312-9-4-5-1X IR 75) and (IR 75) X (IR 60) were the most importance genotypes for heading date trait, while, the genotypes., (Sakha 105), (GZ842312-9-4-5-1),(IR 75), (Giza 179 X IR 60) and (GZ842312-9-4-51X IR 75) were shorter lived and fastest in the blooming flowers, so these genotypes can then be used inbreeding programs for the development of varieties of rice, earlier, resistance to heavy metals, toxic soil, salinity, water stress, high quality attributes and lack of impact on human health, so it is one of the genotypes promising for the advancement of crop Egyptian rice, were the most genotypes for plant height because it was the shorter, can be able to carry a larger number of panicles, so is consider in high yield and can be selected in early generations.

The genotypes., (Sakha 105),(GZ842312-94-5-1), (IR 75),(Giza 179 X IR 60)and (GZ842312-9-4-5-1X IR 75) for number of filled grains /panicle,1000-grain weight and grain yield / plant showed the higher mean values and they were the most expressive for increasing yield and its components compared to other genotypes, while the same observations were recorded for the genotypes, (Sakha 106) and (Sakha 106) X (GZ842312-9-4-5-1) only for grain yield per plant, respectively.

From the analysis ofthe following heavy metals.,( Cadmium , Copper, Cobalt and zinc contents) we observed that the genotypes, (GZ842312-9-4-5-1), (IR 75), (Sakha 105) X (GZ842312-9-4-5-1),(Sakha 106) $X$ (GZ842312-9-4-5-1), (Giza 179) $X$ (IR 60) and (GZ842312-9-4-5-1) X (IR 75),respectively. Were the highest for resistance the toxicity of heavy metals for the fourth traits in Table(3).According to the quantitative analysis of heavy metals, which reflected the resistance of the varieties and their hybrids to the toxicity of these elements, the higher yield and quality were in the varieties that have a permeability 
optional sensitive, accurate and great ability to determine the exactly need for a plant of this element, which is of course the needs of low and this genotypes which containing low percentages of these the four heavy metals are considering the most resistant to the toxicity of heavy metals. Finally the best crosses which were higher of quality, yield of seeds and resistance to the toxicity of heavy metals were (Giza 179) X (IR 60) and (GZ842312-9-4-5-1) X (IR 75)

\section{Variation and Interaction}

Mean squares of half diallel analysis for all traits studied are showed in Table (4). The results revealed that mean squares of all genotypes of rice were found to be highly significant for all traits studied in half diallel analysis, indicating overall differences among these populations. Both general and specific combining ability variances were found to be highly significant for all characters which means, the importance of both additive and non-additive genetic variances in determining the performance of yield components, heavy metals traits and GCA/SCA ratio were used to clarify the nature of the gene action involved. GCA/SCA ratio was found to be greater than unity for all traits studied except heavy metals traits, which were less than the unity, respectively, indicates that additive and additive $\mathrm{x}$ additive types of gene action were greater importance in the inheritance of these traits. Therefore it could be concluded that selection procedures based on the accumulation of additive effects, and would be successful in improving these characters, In addition to the development of promising strains of rice have the ability to tolerance high levels of heavy metals. These findings were in agreement with those reported by El-Said (2007), where he studied plant height, heading date, grain yield, 1000-grain weight and number of filled grains/panicle under normal and drought conditions and recorded that these traits were found to be highly significant for ANOVA analysis and GCA/SCA ratio was found to be greater than unity for 1000-grain weight and grain yield per plant, while the result obtained here it was higher than the unit for the grain yield per plant only.

\section{Heterosis Over Better -Parent}

Significant and highly significant negative of heterosis over better -parent were observed in the crosses, (Sakha 105) $X$ (GZ842312-9-4-5-1), (Sakha 106) X (GZ842312-9-4-5-1), (Giza 179) X (GZ842312-9-4-5-1), (Giza 179) X (IR75), (Giza 179) X (IR60),(GZ842312-9-4-5-1) X (IR75)and (IR75) X (IR60) for heading date and plant height traits and the crosses, (Sakha 105) X (IR75) and (GZ842312-9-45-1) X (IR 60) only for plant height in table (5),On the other hand the crosses, (Sakha 105) X (GZ842312-9-4-5-1), (Sakha 105) X (IR75), (Sakha 106) X (Giza 179), (Sakha 106) X (GZ842312-9-4-5-1),(Sakha 106) X (IR60), (Giza 179) X (GZ842312-9-4-5-1), (Giza 179) X (IR75), (Giza 179) X (IR60), (GZ842312-9-4-5-1) X (IR75) and (IR75) X (IR60) showed highly significant and positive of heterosis over better-parent for Number of filled grains /panicle trait, while the crosses, (Sakha 105) X (Giza 179), (Sakha 105) X (IR75), (Sakha 106) X (Giza 179), (Sakha 106) X (Giza 179), (Sakha 106) $X$ (IR60), (Giza 179) $X$ (IR75), (Giza 179) $X \quad$ (IR60),(GZ842312-9-4-5-1) $X$ (IR75) and (IR75) X (IR60) recorded highly significant and positive of heterosis over better-parent for 1000-grain weight trait, respectively in the same table.

For grain yield / plant trait, highly significant and positive of heterosis over better-parent were observed in the crosses, (Sakha 105)X (GZ842312-9-4-5-1), (Sakha 
106) $X$ (GZ842312-9-4-5-1), (Giza 179) $X$ (IR60) and (GZ842312-9-4-5-1) X (IR75) respectively in table (5).

On the other hand, the previous results in Table 5, showed that the traits Cadmium, Copper, Cobalt and zinc contents not achieved any significant negative values of heterosis over better-parents on the basis of remember that the hybrid vigor of them improved and the image of it was in the negative direction for these traits of heavy metals, except the cross, (Giza179) X (IR60) only which was highly significant and negative of heterosis over better-parent for all heavy metals traits. These findings were in agreement with those reported byElMowafi and AbouShosha (2003), where they studied heterosis for vegetative and grain yield components characters using four cytoplasmic male sterile rice lines and three Egyptian testers (restorers) in a line $\mathrm{x}$ tester analysis and observed that all characters except 1000-grain weight trait showed positive standard heterosis for all the twelve hybrid combinations.

There is no doubt that heterosis over betterparent had given a strong ability for specific combining ability effects for increasing of yield components and also decreasing of the content of heavy metals traits depending on the degree of sovereignty and the interaction of it.(Dominance, dominance $\mathrm{X}$ dominance and additive $\mathrm{X}$ dominance) types of gene action

\section{Combining Ability Effects}

\section{General Combining Ability Effects}

The results in table(6) revealed that the parents, (GZ842312-9-4-5-1) and (IR75) achieved highly significant and negatively of general combining ability effects for heading date, plant height, Cadmium,
Copper, Cobalt and zinc contents respectively, while, these the two parents showed highly significant positively of general combining ability effects for number of filled grains /panicle, 1000-grain weight and grain yield in addition to the parent (Sakha 106) only for grain yield, respectively, which indicated that the importance of additive and additive $\mathrm{X}$ additive types of gene action played an importance role in the inheritance of these traits and the selection for it in early generations will be effective in addition to these parents proving to be good combiners for these traits to resistance of heavy metals in soil, high crop production and recipes achieve premium quality at the local and global level. So, that is the most genetic components in the importance and relevance of this analysis was additive and additive $\mathrm{X}$ additive types of gene action which has great strategic importance for the inheritance of these traits, On the basis of record proportion records(Pedigree) for these parents and followed during hybridization processes (half diallel system) of reciprocal access to production high purity of the strains, high yield and quality of seeds, resistance to abiotic stress such as heavy metals and this is not only on the basis of the strength and the biggest ability for physiological system to prevent Into force of high levels of heavy metals, prevent toxicity and its impact of Egyptian human health.

\section{Specific Combining Ability Effects}

The genotypes, (Sakha 106) X (GZ8423129-4-5-1), (Sakha 106) X (IR 75), (Giza 179) X (GZ842312-9-4-5-1), (Giza 179) x (IR 75) and (IR 75) X (IR 60) for heading date and plant height traits and (Sakha 105) $X$ (GZ842312-9-4-5-1) for heading date trait only and (Sakha 105) X (IR75) for plant height trait only, respectively, showed highly significant and negative of specific 
combining ability effects, while, the genotypes, (Sakha 105) X (GZ842312-9-45-1), (Sakha 105) X (IR75), (Sakha 106) X (GZ842312-9-4-5-1), (Sakha 106) X (IR 75), (Sakha 106) X (IR 60), (GZ842312-9-45-1) $X$ (IR75) and (IR75) $X$ (IR60) for number of filled grains /panicle and 1000grain weight and (Giza 179) $X$ (IR75) and (Giza 179) X (IR60) for number of filled grains /panicle only and (Sakha 105) X (Giza 179) and (Sakha 106) x (Giza 179) for 1000-grain weight only, revealed significant and highly significant positive of specific combining ability effects, respectively. On the other hand the genotypes, (Sakha 105) X (GZ842312-9-4-5-1), (Sakha 105) X (IR75), (Sakha 106) X (GZ842312-9-4-5-1) and (Sakha 106) X (IR 75) showed significant and highly significant positive of specific combining ability effects for grain yield, respectively, in table (7) and the other the results indicated that, the crosses, (Sakha 105) X (GZ842312-9-4-5-1), (Sakha 105) X (IR75), (Sakha 106) X (GZ842312-9-4-5-1) and (Sakha 106) X (IR 75), (Giza 179) X (GZ842312-9-4-5-1) and (IR75) X (IR60) for Cadmium and copper contents, the crosses (Giza 179) X (IR75) for cadmium content only and (GZ842312-9-4-5-1) X (IR60) for copper content only too, showed significant and highly significant negative of specific combining ability effects ,respectively and if we discussed thoroughly in the rest of the results in Table (7), we find the following genotypes, (Sakha 105) $X$ (GZ842312-9-4-5-1), (Sakha 105) X (IR75), (Sakha 106) X (GZ842312-9-4-5-1), (Giza 179) $X$ (GZ842312-9-4-5-1) for cobalt and zinc content and the genotypes, (Sakha 105) $\mathrm{X}$ (IR60) for cobalt contents only and the crosses, (Sakha 105) X (Sakha 106) and (IR 75) $X$ (IR60) for zinc contents only were showed significant and highly significant negative of specific combining ability effects, respectively. Which explains that the dominance, dominance $\mathrm{X}$ dominance, additive $\mathrm{X}$ dominance and epistasis types of gene interaction played a large role in the inheritance of these traitsin early generations and had avital role to compare between crosses about highly yield and the least in the contents of heavy metals, thus can follow these crosses by continuing in agriculture and selection alternately to reach of these lines of rice to fixed genetically on the local scale which resistance to the toxicity of heavy metals and is also resistant to soil salinity.

These results were in agreement with those reported by El-Mowafi and Abou Shousha (2003), Fahmi et al., (2004), Ghosh et al., (2012), Latha et al., (2013), Raju ( et al.,2014) and Hasan et al., (2015)where all characters studied were highly significant and positive of specific combining ability effects, while, disagree with them in that heading date and plant height traits were negatively and highly significant of specific combining ability effects in the present study on the contrary to the results of the other papers, in addition to these papers do not study the level of heavy metals in the leaves of rice, While, their interpretation of specific combining ability effects for yield and its components was on the based of the traditional appreciation for the genetic basis and determining genetic mechanisms responsible for increasing the yield and its components and under normal conditions only without study for any stress

\section{Molecular Studies}

Gel analysis: RAPD data analysis the fragments were recorded in presence and absence of fragments on gel photographs figure (1 a, b, c, d, e, f and g).

Using RAPD-PCR technique of seven primers revealed 51 fragments, where 38 of them were polymorphic bands with $74.51 \%$ 
polymorphism and 13 were monomorphic bands with $25.49 \%$. The band size was range between 160 to $2344 \mathrm{bp}$. The seven primers give average of 7.28 bands/ primer, as show in Figure 1and Table (8).

The primer (OPA-02) revealed eight bands. Two of them were monomorphic and six were polymorphic with percentage $75 \%$ polymorphism Fig. 1a and Table (8). Primer (OPA-04) showed six amplicons four of six were polymorphic with $66.667 \%$ polymorphism and range size of bands was
558 to $1149 \mathrm{bp} \mathrm{Fig.} 1 \mathrm{~b}$ and Table (8),and the third one detected eight variable bands with polymorphism 87.5 Fig. 1c and Table (8).

While, primer (OPB-07) gives seven fragments, five were polymorphic with $71.428 \%$ of polymorphism ranged from 160 to1020bp.

Primes OPB-10, OPO-10 and OPO-13 revealed 6,6 and 10 bands respectively, with polymorphism 50, 83.3and $80 \%$, respectively.

Table.1 The Pedigree and Reaction for Heavy Metals in the Genotypes of Rice

\begin{tabular}{|c|c|c|}
\hline Genotypes & The pedigree & $\begin{array}{c}\text { Reaction for } \\
\text { Heavy metals }\end{array}$ \\
\hline P1(Sakha 105) & Giza 176/Gz-4-8-9-1 & Susceptible \\
\hline P2(Sakha 106) & GZ 4523-6-7-3-2/IR-2-6-2-1 & Susceptible \\
\hline P3(Giza 179) & SK-3-1-8-3/Gz123-6-4-1/TA14 & Moderate \\
\hline P4 (GZ842312-9-4-5-1) & Giza172/IR-3-4-7-1/IR3-5-2-31-8 & Susceptible \\
\hline P5 (IR 75) & GZ-45-3-9-5-4-3-2-1/GZ456-8-4-1 & Tolerance \\
\hline P6 (IR 60) & IRAT 16-3-7-8-5-2-1/GZ23-5-6-3-1 & Tolerance \\
\hline
\end{tabular}

Table.2 Code and Sequences of Seven RAPD Primers

\begin{tabular}{|c|c|c|}
\hline Number code & Sequence $\left(5^{`} \rightarrow 3^{`}\right)$ & Primer code \\
\hline 1 & CAGGCCCTTC & OPA-02 \\
\hline 2 & AATCGGGCTG & OPA-04 \\
\hline 3 & GAAACGGGTG & OPA-07 \\
\hline 4 & GGTGACGCAG & OPB-07 \\
\hline 5 & CTGCTGGGAC & OPB-10 \\
\hline 6 & TCAGAGCGCC & OPO-10 \\
\hline 7 & GTCAGAGTCC & OPO-13 \\
\hline
\end{tabular}


Table.3 Means of Parents and their F1 Crosses for all Studied Traits in Rice

\begin{tabular}{|c|c|c|c|c|c|c|c|c|c|}
\hline Genotypes & $\begin{array}{c}\text { Heading } \\
\text { date }\end{array}$ & $\begin{array}{l}\text { Plant } \\
\text { height }\end{array}$ & $\begin{array}{l}\text { Number of } \\
\text { filled grains } \\
\text { /panicle }\end{array}$ & $\begin{array}{c}\text { 1000-grain } \\
\text { weight }\end{array}$ & $\begin{array}{c}\text { Grain } \\
\text { yield }\end{array}$ & $\begin{array}{c}\text { Cadmium } \\
\text { Co }\end{array}$ & Copper Co & Cobalt Co & Zinc Co \\
\hline P1(Sakha105) & 102.00 & 95.00 & 152.23 & 27.00 & 41.00 & 2.88 & 3.80 & 1.20 & 32.07 \\
\hline P2(Sakha106) & 93.00 & 101.33 & 132.00 & 22.33 & 54.00 & 2.53 & 5.85 & 0.73 & 24.00 \\
\hline P3(Giza179) & 107.00 & 111.00 & 141.00 & 26.33 & 35.67 & 3.80 & 3.77 & 1.23 & 16.67 \\
\hline $\begin{array}{l}\text { P4(GZ842312-9- } \\
4-5-1)\end{array}$ & 91.00 & 96.00 & 176.00 & 36.00 & 61.00 & 0.54 & 0.94 & 0.24 & 10.33 \\
\hline P5(IR75) & 94.33 & 102.67 & 189.00 & 35.33 & 66.00 & 0.40 & 0.81 & 0.05 & 8.59 \\
\hline P6(IR60) & 98.67 & 111.33 & 123.33 & 20.67 & 27.00 & 2.32 & 5.89 & 0.81 & 23.00 \\
\hline P1 X P2 & 115.00 & 120.00 & 109.00 & 19.00 & 21.00 & 5.03 & 6.57 & 2.53 & 37.00 \\
\hline P1 X P3 & 108.00 & 111.33 & 137.00 & 31.00 & 32.00 & 3.70 & 5.33 & 1.95 & 31.20 \\
\hline P1 X P4 & 87.33 & 90.00 & 204.67 & 37.50 & 64.50 & 0.22 & 0.77 & 0.14 & 10.39 \\
\hline P1 X P5 & 96.00 & 90.67 & 196.00 & 38.50 & 56.67 & 0.42 & 0.64 & 0.12 & 10.75 \\
\hline P1 X P6 & 114.00 & 118.00 & 116.33 & 19.50 & 21.67 & 3.22 & 4.50 & 0.94 & 31.57 \\
\hline P2 X P3 & 111.00 & 115.00 & 146.00 & 30.83 & 41.33 & 4.17 & 4.86 & 1.59 & 21.00 \\
\hline P2 X P4 & 88.00 & 90.00 & 183.00 & 38.00 & 64.83 & 0.17 & 0.63 & 0.33 & 8.45 \\
\hline P2 X P5 & 117.00 & 122.00 & 107.00 & 18.33 & 20.00 & 4.29 & 7.59 & 2.26 & 40.96 \\
\hline P2 X P6 & 107.00 & 118.00 & 137.00 & 28.00 & 24.83 & 3.04 & 5.23 & 1.60 & 22.67 \\
\hline P3 X P4 & 86.00 & 91.00 & 209.00 & 33.00 & 45.00 & 0.42 & 0.98 & 0.04 & 8.87 \\
\hline P3 X P5 & 91.00 & 100.00 & 196.00 & 40.00 & 52.83 & 0.19 & 1.19 & 0.41 & 12.17 \\
\hline P3X P6 & 84.00 & 88.00 & 246.00 & 41.83 & 79.50 & 0.04 & 0.21 & 0.02 & 7.63 \\
\hline P4 X P5 & 85.33 & 87.00 & 240.00 & 44.00 & 69.00 & 0.03 & 0.31 & 0.07 & 6.49 \\
\hline P4 X P6 & 105.00 & 89.67 & 113.67 & 26.00 & 39.00 & 3.53 & 0.67 & 1.59 & 21.67 \\
\hline P5 X P6 & 90.00 & 100.00 & 227.00 & 39.00 & 41.67 & 0.20 & 0.73 & 0.38 & 8.67 \\
\hline LSD 0.05 & 1.94 & 1.97 & 2.51 & 2.27 & 2.09 & 0.74 & 0.79 & 0.36 & 4.75 \\
\hline 0.01 & 2.60 & 2.64 & 3.36 & 3.03 & 2.80 & 0.99 & 1.06 & 0.48 & 6.36 \\
\hline
\end{tabular}


Table.4 Mean Squares of Different Genotypes of Rice for all Traits Studied

\begin{tabular}{|c|c|c|c|c|c|c|c|c|c|c|}
\hline S.O.V & D.F & $\begin{array}{c}\text { Heading } \\
\text { date }\end{array}$ & $\begin{array}{c}\text { Plant } \\
\text { height }\end{array}$ & $\begin{array}{l}\text { Number of filled } \\
\text { grains /panicle }\end{array}$ & $\begin{array}{c}\text { 1000-grain } \\
\text { weight }\end{array}$ & $\begin{array}{l}\text { Grain } \\
\text { yield }\end{array}$ & $\begin{array}{c}\text { Cadmium } \\
\text { Content }\end{array}$ & $\begin{array}{l}\text { Copper } \\
\text { Content }\end{array}$ & $\begin{array}{c}\text { Cobalt } \\
\text { Content }\end{array}$ & $\begin{array}{c}\text { Zinc } \\
\text { Content }\end{array}$ \\
\hline Replications & 2 & 1.64 & 1.48 & 4.27 & 1.39 & 3.32 & 0.17 & 0.16 & 0.06 & 16.31 \\
\hline Genotypes & 20 & $282.92 * *$ & $336.89 * *$ & $3941.22 * *$ & $199.03 * *$ & 875.13 ** & $7.60 * *$ & $16.01 * *$ & $1.30 * *$ & $241.26 * *$ \\
\hline GCA & 5 & $215.39 * *$ & $268.94 * *$ & $3134.77 * *$ & $176.88 * *$ & $929.64 * *$ & $6.94 * *$ & $16.29 * *$ & $1.00 * *$ & $220.92 * *$ \\
\hline SCA & 15 & $53.95 * *$ & $60.08 * *$ & $706.73 * *$ & $29.50 * *$ & $79.07 * *$ & $1.06 * *$ & $1.68 * *$ & $0.25 * *$ & $33.58 * *$ \\
\hline Error & 40 & 1.39 & 1.43 & 2.32 & 1.89 & 1.61 & 0.20 & 0.23 & 0.05 & 8.30 \\
\hline GCA/ SCA & & 0.50 & 0.56 & 0.55 & 0.76 & 1.48 & 0.86 & 1.26 & 0.53 & 0.88 \\
\hline
\end{tabular}

*and $* *$ indicate significant at 0.05 and 0.01 levels of probability, respectively

Table.5 Estimates of Heterosis over Better -Parent (B.P) of F1 Rice Crosses for all Studied Traits

\begin{tabular}{|c|c|c|c|c|c|c|c|c|c|}
\hline Crosses & Heading date & Plant height & $\begin{array}{l}\text { Number of filled } \\
\text { grains /panicle }\end{array}$ & $\begin{array}{c}\text { 1000-grain } \\
\text { weight }\end{array}$ & Grain yield & Cadmium Co & Copper Co & Cobalt Co & Zinc Co \\
\hline $\mathrm{P}_{1} \times \mathrm{p}_{2}$ & $23.65 * *$ & $26.31 * *$ & $-28.39 * *$ & $-29.63 * *$ & $-61.11 * *$ & $98.81 * *$ & $72.89 * *$ & $246.57 * *$ & $54.16 * *$ \\
\hline $\mathrm{P}_{1} \times \mathrm{p}_{3}$ & $5.88 * *$ & $17.18 * *$ & $-10.01 * *$ & $14.81^{* *}$ & $-21.95^{* *}$ & $28.47 *$ & $41.38 * *$ & $62.50 * *$ & $87.16^{* *}$ \\
\hline $\mathrm{P}_{1} \times \mathrm{p}_{4}$ & $-4.03 * *$ & $-5.26 * *$ & $16.29 * *$ & 4.17 & $5.74 * *$ & -59.25 & -18.08 & -41.66 & 0.58 \\
\hline $\mathrm{P}_{1} \times \mathrm{p}_{5}$ & 1.77 & $-4.55 * *$ & $3.70 * *$ & $8.96 * *$ & $-14.14 * *$ & 5.0 & -20.98 & 140.0 & 25.14 \\
\hline $\mathrm{P}_{1} \times \mathrm{p}_{6}$ & $15.54 * *$ & $24.21 * *$ & $-23.58 * *$ & $-27.78 * *$ & $-47.15 * *$ & $38.79 *$ & 18.42 & 16.04 & $37.26 * *$ \\
\hline $\mathrm{P}_{2} \mathrm{Xp}_{4}$ & $-3.30 * *$ & $-6.25 * *$ & $3.98 * *$ & 5.56 & $6.28 * *$ & -68.51 & -32.97 & 37.50 & -18.19 \\
\hline $\mathrm{P}_{2} \mathrm{xp}_{5}$ & $25.80 * *$ & $20.39 * *$ & $-43.38 * *$ & $-48.11 * *$ & $-69.69 * *$ & $972.5^{* *}$ & $837.03 * *$ & $4420.0 * *$ & $376.83 * *$ \\
\hline $\mathrm{P}_{2} \mathrm{xp}_{6}$ & $15.05 * *$ & $16.45 * *$ & $3.79 * *$ & $25.37 * *$ & $-54.01 * *$ & $31.03 *$ & -10.60 & $119.18^{* *}$ & -1.43 \\
\hline $\mathrm{P}_{3} \mathrm{Xp}_{4}$ & $-5.49 * *$ & $-5.20 * *$ & $18.75 * *$ & $-8.33^{*}$ & $-26.23 * *$ & -22.22 & 4.25 & -83.33 & -14.13 \\
\hline $\mathrm{P}_{3} \mathrm{xp}_{5}$ & $-3.53 * *$ & $-2.60 * *$ & $3.70 * *$ & $13.21 * *$ & $-19.95 * *$ & -52.50 & $46.91 * *$ & $720.00 *$ & 41.67 \\
\hline $\mathrm{P}_{3} \mathrm{xp}_{6}$ & $-14.86 * *$ & $-20.72 * *$ & $99.46 * *$ & $58.86 * *$ & $122.87 * *$ & $-98.27 * *$ & $-94.42 * *$ & $-97.53 * *$ & $-54.22 * *$ \\
\hline $\mathrm{P}_{4} \mathrm{xp}_{6}$ & $15.38 * *$ & $-6.59 * *$ & $-35.42^{* *}$ & $-27.78 * *$ & $-36.07 * *$ & $553.70 * *$ & -28.72 & $562.50 * *$ & $109.77^{* *}$ \\
\hline $\mathrm{P}_{5} \mathrm{xp}_{6}$ & $-4.59 * *$ & $-2.60 * *$ & $20.11 * *$ & $10.38 * *$ & $-36.87 * *$ & -50.00 & -9.87 & 660.00 & 0.93 \\
\hline LSD 0.05 & 1.94 & 1.97 & 2.51 & 2.27 & 2.09 & 0.74 & 0.79 & 0.36 & 4.75 \\
\hline 0.01 & 2.60 & 2.64 & 3.36 & 3.03 & 2.80 & 0.99 & 1.06 & 0.48 & 6.36 \\
\hline
\end{tabular}

$*$ and $* *$ indicate significant at 0.05 and 0.01 levels of probability, respectively 
Table.6 Estimates of General Combining Ability Effects of all Rice Parents for all Studied Characters

\begin{tabular}{|c|c|c|c|c|c|c|c|c|c|}
\hline Parents & $\begin{array}{c}\text { Heading } \\
\text { date }\end{array}$ & $\begin{array}{c}\text { Plant } \\
\text { height }\end{array}$ & $\begin{array}{l}\text { Number of filled } \\
\text { grains /panicle }\end{array}$ & $\begin{array}{c}\text { 1000-grain } \\
\text { weight }\end{array}$ & Grain yield & $\begin{array}{c}\text { Cadmium } \\
\text { Co }\end{array}$ & Copper Co & Cobalt Co & Zinc Co \\
\hline (Sakha 105) & $3.76 * *$ & -0.29 & $-8.66 * *$ & $-2.11 * *$ & $-4.83 * *$ & $0.42 * *$ & $0.71 * *$ & $0.16^{* *}$ & $5.33 * *$ \\
\hline (Sakha 106) & $0.47 *$ & $2.67 * *$ & $-12.22 * *$ & $-1.94 * *$ & $1.81 * *$ & $0.34 * *$ & $1.23 * *$ & $0.12 * *$ & 0.71 \\
\hline (Giza 179) & $4.10 * *$ & $4.88 * *$ & $-5.09 * *$ & $-1.51 * *$ & $-6.81 * *$ & $0.87 * *$ & $0.66 * *$ & $0.32 * *$ & $1.85 * *$ \\
\hline (GZ842312-9-4-5-1) & $-6.94 * *$ & $-9.21 * *$ & $15.20 * *$ & $4.26 * *$ & $10.98 * *$ & $-0.94 * *$ & $-1.81 * *$ & $-0.36 * *$ & $-5.73 * *$ \\
\hline (IR 75) & $-5.90 * *$ & $-4.04 * *$ & $32.03 * *$ & $7.01 * *$ & $13.33 * *$ & $-1.38 * *$ & $-1.83 * *$ & $-0.52 * *$ & $-7.02 * *$ \\
\hline (IR 60) & $4.51 * *$ & $6.00 * *$ & $-21.26 * *$ & $-5.72 * *$ & $-14.48 * *$ & $0.69 * *$ & $1.04 * *$ & $0.28 * *$ & $4.85 * *$ \\
\hline LSD 0.05 & 0.44 & 0.45 & 0.57 & 0.52 & 0.48 & 0.17 & 0.18 & 0.08 & 1.08 \\
\hline LSD 0.01 & 0.59 & 0.60 & 0.77 & 0.69 & 0.64 & 0.23 & 0.24 & 0.11 & 1.45 \\
\hline
\end{tabular}

*and ** indicate significant at 0.05 and 0.01 levels of probability, respectively

Table.7 Estimates of Specific Combining Ability Effects of F1 Crosses for all Studied Traits in Rice

\begin{tabular}{|c|c|c|c|c|c|c|c|c|c|}
\hline Crosses & $\begin{array}{l}\text { Heading } \\
\text { date }\end{array}$ & $\begin{array}{l}\text { Plant } \\
\text { height }\end{array}$ & $\begin{array}{l}\text { Number of filled grains } \\
\text { /panicle }\end{array}$ & $\begin{array}{l}\text { 1000-grain } \\
\text { weight }\end{array}$ & $\begin{array}{l}\text { Grain } \\
\text { yield }\end{array}$ & $\begin{array}{l}\text { Cadmium } \\
\text { Co }\end{array}$ & $\begin{array}{l}\text { Copper } \\
\text { Co }\end{array}$ & $\begin{array}{l}\text { Cobalt } \\
\text { Co }\end{array}$ & $\begin{array}{c}\text { Zinc } \\
\text { Co }\end{array}$ \\
\hline $\mathrm{P}_{1} \times \mathrm{p}_{2}$ & $8.16 * *$ & $10.15 * *$ & $-15.37 * *$ & $-7.86 * *$ & $-21.19 * *$ & 0.41 & $1.81 * *$ & $0.42 * *$ & $-3.10 *$ \\
\hline $\mathrm{P}_{1} \times \mathrm{p}_{3}$ & $1.54 *$ & $4.27 * *$ & $-14.50 * *$ & $3.71 * *$ & $-1.57 *$ & $0.55^{*}$ & $1.14 * *$ & $0.64 * *$ & $5.96 * *$ \\
\hline $\mathrm{P}_{1} \times \mathrm{p}_{4}$ & $-8.09 * *$ & $2.98 * *$ & $32.88 * *$ & $4.44 * *$ & $13.14 * *$ & $-1.11 * *$ & $-0.95 * *$ & $-0.49 * *$ & $-7.26 * *$ \\
\hline $\mathrm{P}_{1} \times \mathrm{p}_{5}$ & -0.46 & $-7.48 * *$ & $7.38 * *$ & $2.69 * *$ & $2.95 * *$ & $-0.47^{*}$ & $-1.06 * *$ & $-0.35 * *$ & $-5.62 * *$ \\
\hline $\mathrm{P}_{1} \times \mathrm{p}_{6}$ & $7.12 * *$ & $9.82 * *$ & $-19.00 * *$ & $-3.59 * *$ & $-4.24 * *$ & 0.25 & -0.07 & $-0.32 * *$ & $3.33 *$ \\
\hline $\mathrm{P}_{2} \mathrm{Xp}_{3}$ & $7.83 * *$ & $4.98 * *$ & $-1.94 *$ & $3.37 * *$ & 1.12 & $1.09 * *$ & 0.14 & $0.33 * *$ & 0.38 \\
\hline $\mathrm{P}_{2} \mathrm{Xp}_{4}$ & $-4.13 * *$ & $-5.94 * *$ & $14.77 * *$ & $4.77 * *$ & $6.83 * *$ & $-1.09 * *$ & $-1.61 * *$ & $-0.26 *$ & $-4.59 * *$ \\
\hline $\mathrm{P}_{2} \mathrm{Xp}_{5}$ & $-2.17 * *$ & $-3.10 * *$ & $14.94 * *$ & $4.35 * *$ & $10.64 * *$ & $-0.53 *$ & $-1.63 * *$ & -0.16 & -0.79 \\
\hline $\mathrm{P}_{2} \mathrm{xp}_{6}$ & $3.41 * *$ & $6.86 * *$ & $5.23 * *$ & $4.75 * *$ & $-7.71 * *$ & 0.14 & 0.14 & $0.37 * *$ & -0.95 \\
\hline $\mathrm{P}_{3} \mathrm{xp}_{4}$ & $-9.76^{* *}$ & $-7.14 * *$ & $33.65 * *$ & -0.67 & $-4.38 * *$ & $-1.37 * *$ & $-0.69 * *$ & $-0.75 * *$ & $-5.31 * *$ \\
\hline $\mathrm{P}_{3} \mathrm{Xp}_{5}$ & $-5.80 * *$ & $-3.31 * *$ & $3.81 * *$ & 3.58 & 1.10 & $-1.16 * *$ & -0.46 & -0.21 & -0.72 \\
\hline $\mathrm{P}_{3} \times \mathrm{xp}_{6}$ & $5.79 * *$ & $3.65 * *$ & $7.10 * *$ & $-6.86 * *$ & $-4.42 * *$ & $0.49 *$ & $0.63 *$ & $0.45 * *$ & $9.87 * *$ \\
\hline $\mathrm{P}_{4} \mathrm{xp}_{5}$ & 0.58 & $1.77 * *$ & $3.52 * *$ & $1.81 *$ & -0.53 & $0.50 *$ & $1.13 * *$ & $0.38 * *$ & $5.19 * *$ \\
\hline $\mathrm{P}_{4} \mathrm{xp}_{6}$ & $8.83 * *$ & $-9.60 * *$ & $-45.52 * *$ & $-3.46 * *$ & $-2.71 * *$ & $1.92 * *$ & $-1.38 * *$ & $0.84 * *$ & $4.49 * *$ \\
\hline $\mathrm{P}_{5} \mathrm{xp}_{6}$ & $-7.21 * *$ & $-4.44 * *$ & $50.98 * *$ & $6.79 * *$ & $-2.40 * *$ & $-0.97 * *$ & $-1.30 * *$ & -0.20 & $-7.22 * *$ \\
\hline LSD 0.05 & 1.22 & 1.24 & 1.57 & 1.42 & 1.31 & 0.47 & 0.49 & 0.22 & 2.98 \\
\hline LSD 0.01 & 1.63 & 1.65 & 2.11 & 1.90 & 1.75 & 0.62 & 0.66 & 0.30 & 3.99 \\
\hline
\end{tabular}

*and ** indicate significant at 0.05 and 0.01 levels of probability, respectively 
Table.8 Total Number, Monomorphic, Polymorphic of Bands and Percentage of Polymorphism as Revealed by Seven RAPD primers on Ten Genotypes of Rice

\begin{tabular}{|c|c|c|c|c|c|c|}
\hline Primer code & Total bands & Monomorphic bands & $\begin{array}{l}\text { Polymorphic } \\
\text { bands }\end{array}$ & Unique bands & polymorphism\% & $\begin{array}{l}\text { Range size of bands } \\
\text { (bp) }\end{array}$ \\
\hline OPA-02 & 8 & 2 & 4 & 2 & $75 \%$ & $168: 932$ \\
\hline OPA-04 & 6 & 2 & 4 & 0 & $66.667 \%$ & $558: 1149$ \\
\hline OPA-07 & 8 & 1 & 5 & 2 & $87.5 \%$ & $180: 750$ \\
\hline OPB-07 & 7 & 2 & 4 & 1 & $71.428 \%$ & $160: 1020$ \\
\hline OPB-10 & 6 & 3 & 2 & 1 & $50 \%$ & $184: 869$ \\
\hline OPO-10 & 6 & 1 & 4 & 1 & $83.333 \%$ & $178: 736$ \\
\hline OPO-13 & 10 & 2 & 7 & 1 & $80 \%$ & $292: 2344$ \\
\hline Total bands & $51(100 \%)$ & $13(25.49 \%)$ & $30(58.82 \%)$ & $8(15.68 \%)$ & $74.51 \%$ & $160: 2344$ \\
\hline
\end{tabular}

Table.9 Similarity Matrix between Two Groups (Six Parents p1:p6 and Four Hybrids H1:H4 of Rice Genotypes

\begin{tabular}{|c|c|c|c|c|c|c|c|c|c|c|}
\hline \multirow[t]{2}{*}{ Case } & \multicolumn{10}{|c|}{ Matrix File Input } \\
\hline & $\mathrm{P} 1$ & $\mathrm{P} 2$ & P3 & $\mathrm{P} 4$ & $\mathrm{P} 5$ & P6 & $\mathrm{H} 1$ & $\mathrm{H} 2$ & $\mathrm{H} 3$ & $\mathrm{H} 4$ \\
\hline $\mathrm{P} 1$ & 1.000 & & & & & & & & & \\
\hline $\mathrm{P} 2$ & .761 & 1.000 & & & & & & & & \\
\hline $\mathrm{P} 3$ & .924 & 1.000 & 1.000 & & & & & & & \\
\hline $\mathrm{P} 4$ & .299 & .237 & .122 & 1.000 & & & & & & \\
\hline P5 & .825 & .761 & .782 & .477 & 1.000 & & & & & \\
\hline P6 & .430 & .674 & .411 & .365 & .584 & 1.000 & & & & \\
\hline $\mathrm{H} 1$ & .411 & .347 & .229 & .332 & .584 & .122 & 1.000 & & & \\
\hline $\mathrm{H} 2$ & .584 & .674 & .555 & .365 & .738 & .332 & .299 & 1.000 & & \\
\hline $\mathrm{H} 3$ & .584 & .373 & .411 & .000 & .430 & .332 & .122 & .174 & 1.000 & \\
\hline $\mathrm{H} 4$ & .782 & .723 & .877 & .122 & .924 & .555 & .229 & .411 & .700 & 1.000 \\
\hline
\end{tabular}


Fig.1 a, b, c, d, e, f and g. RAPD- PCR Banding Patterns of Ten Rice Genotypes using Primers, OPA-02,OPA-04, OPA-07, OPB-07, OPB-10, OPO-10 and OPO-13. M = 1500bp: 100bp Ladder Marker

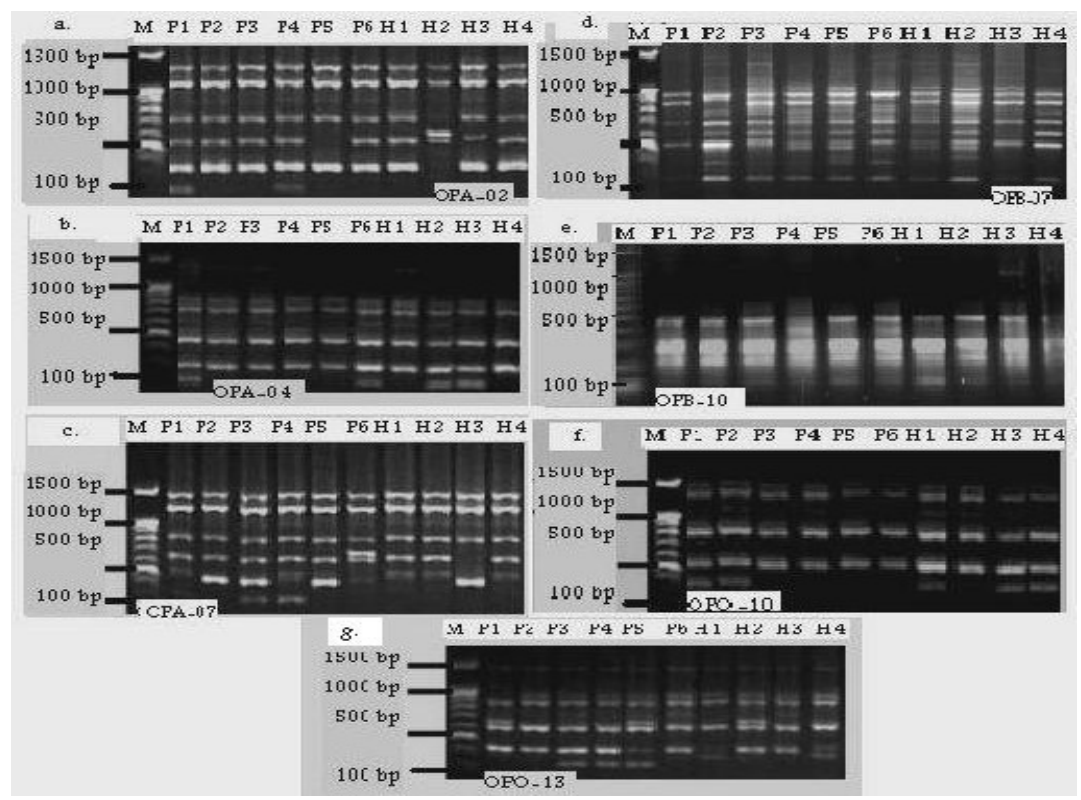

Fig.2 Dendrogram of the Genetic Distances among the Ten Rice Genotypes Based on RAPD Analysis

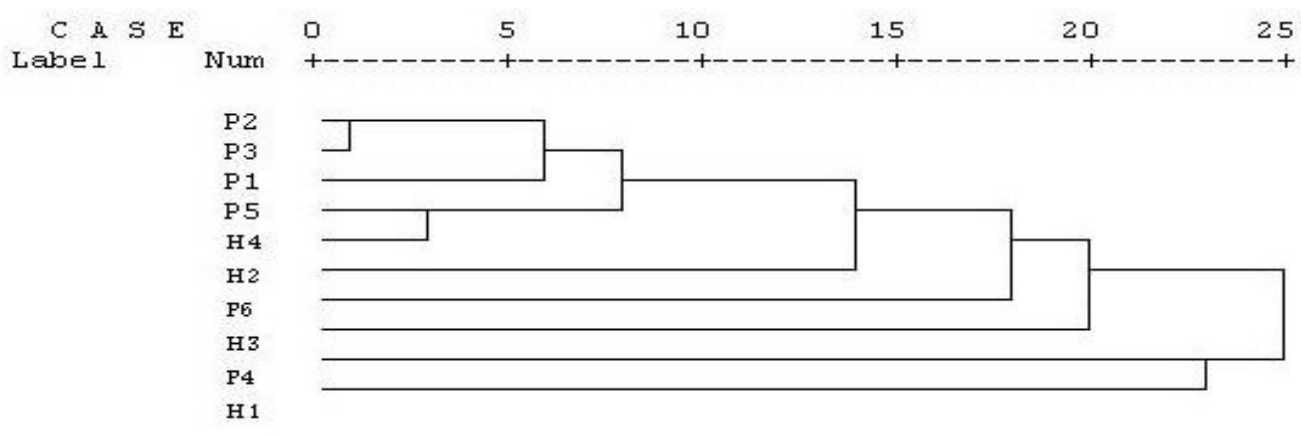


Proximity matrix analysis:-revealed the genetic relationships among all genotypes were estimated in terms of similarity using Dice coefficient, these results showed in Fig. 2 and Table (9). RAPD markers used to figure out the rice genotypes relationships by UPGMA of the dendrogram, and in the Proximity matrix distinguished relationships between six parents and four hybrids, where the similarity was $78.2 \%$ between $\mathrm{P} 1$ with $\mathrm{H} 4$ (0.282). These relationships were also shown in dendrogram using average linkage (between groups), where P2 gives 72.3and $67.4 \%$ similarities with $\mathrm{H} 4$ and $\mathrm{H} 3$ respectively. From one site P3 revealed high similarity with $\mathrm{H} 4(87.7 \%)$ and middle ratio with $\mathrm{H} 2(55.5 \%)$ and lowest ratio of similarities were between P3 with the two hybrids $\mathrm{H} 3$ and $\mathrm{H} 1$ by 41.1 and $22.9 \%$, respectively. On the other site $\mathrm{P} 4$ showed the lowest similarity with the four hybrids, and P5 gave the high values of similarity $92.4 \%$ with $\mathrm{H} 4$ and $73.3 \%$ with $\mathrm{H} 2$, while P6 give $55.5 \%$ with $\mathrm{H} 4$ and the lowest values of similarity was between P6 with other hybrids. The results may throw the lights on the possibility of using four parents (P1, P2, P3 and P5) in the upcoming breeding programs, and impossibility of using P4 and P6 in breeding programs of rice.

Genetic similarity: The RAPD data matrix (Table 9) was utilized to estimate the genetic similarity among the genotypes. Genetic similarity ranged from 0.924 to 0.122 across all genotypes. The mean value of genetic similarity was 0.523 . The phylogenetic tree divided to clusters the first one included $\mathrm{p} 2$, p3, p1, p5 H4, H2, p6 and $\mathrm{H} 3$ respectively, while, the last cluster include only $\mathrm{p} 4$ and $\mathrm{H} 1$ from the far to the nearest in genetic relationships.

Uses of RAPDs as a tool to study the genetic diversity and relationships among different cultivars have previously been reported
(Chalmers et al., 1992; Landry et al., 1994; Porreca et al., 2001; Neeraja et al., 2002; Rabbani et al., 2008).Similarity index for accessions varied from 0.122 to 0.924 with an average value of 0.523 . Similar levels of diversity have been reported previously among various panels of rice genotypes under different analysis (Davierwala et al., 2000; Ren et al., 2003). However, relatively higher similarity value $(90 \%)$ with 25 to $77.5 \%$ (Raghunathachari et al., 2000) and Panagal et al., (2010) carried out RAPDPCR reactions by using 2 random primers, and total 27 scrabble bands were determined in four species of rice varieties ranging from $1600 \mathrm{bp}$ to $300 \mathrm{bp}$. While, in this study using seven primers determine 51 bands ranging from $2344 \mathrm{bp}$ to $160 \mathrm{bp}$.

In conclusion, from this investigation it was observed that the genotypes,(Sakha 106), (GZ842312-9-4-5-1),(IR 75), ( (Giza 179 X IR 60) and (GZ842312-9-4-5-1X IR 75) were the best regarding to higher yielding tolerant to the accumulation of heavy metals in the cell juice in securities of rice. The results of general and specific combining ability effects showed that the use of these crosses is considered at the molecular level, useful process to obtain the stable genetic lines which are tolerant to the toxicity of heavy metals. On the other hand, combining the molecular markers and AMOVA analysis supported the genetic relationships among the ten rice genotypes as modern breeding approaches, and it could be successfully used to improve the tolerance of heavy metals toxicity in the promising rice genotypes.

\section{References}

Chalmers, K.J., R. Waugh, J.I. Sprent, A.J. Simons and W. Powell (1992).Detection of genetic variation between and within populations of 
Gliricidiasepium and G. maculate using RAPD markers. Heredity, 69: 465-472. Chander K, Dyckmans J, Hoeper H, Joergensen RG, Raubuch M (2001b).Industrial exhaust depositions as sources of heavy metals and their long-term effects on microbial soil properties. J Plant Nutr Soil Sci. 164:657-663.

Chander K, Dyckmans J, Joergensen RG, Meyer B, Raubuch M. (2001a).Different sources of heavy metals and their long-term effects on soil microbial properties. BiolFertil Soils. 34:241-247.

Davierwala, A.P., K.V. Chowdari, S. Kumar, A.P.K. Reddy, P.K. Ranjekar and V.S. Gupta. (2000). Use of three different marker systems to estimate genetic diversity of Indian elite rice varieties. Genetica, 108: 269-284.

Dospatliev, L., Kostadinov, K., Mihaylova, G., Katrandzhiev, N.(2012). DETERMINATION OF HEAVY METALS ( $\mathrm{Pb}, \mathrm{Zn}, \mathrm{Cd}$ and $\mathrm{Ni})$ IN EGGPLANT.Trakia Journal of Sciences, Vol. 10, No 2, 31-35.

El-Mowafi, H.F. and A.A. AbouShousha (2003).Combining ability and heterosis analysis of divers CMS lines in hybrid rice. J. Agric. Res. Tanta Univ., 29(1): 106-127.

El-Said, A.M. (2007).Genetical and molecular breeding for drought tolerance in Rice, Department of Genetics, Faculty of Agriculture, Kafr El-Sheikh University.

Fahmi, A.I.; I.R. Aidy; H.H. Nagaty and M.M. El-Malky (2004).Combining ability and relationship among some Egyptian and exotic rice varieties.Abstracts of the International Conference on Advanced Rice Research. Alexandria, Egypt.

Ghoshi S. C., P. K. Chandrakar,N. K. Rastogi, D. Sharma and A. K. Sarawgi
(2012).Combining ability analysis using CMS breeding system for developing hybrids in rice (Oriza sativa). Bangladesh J. Agril. Res. 37(4): 583-592.

Griffing J.B. (1956).Concept of general and specific combining ability in relation to diallel crossing systems. Australian J. of Biol. Sci., 9: 463-493.

Gupta, P.K., R.K. Varshney, P.C. Sharma and B. Remash.(1999). Molecular markers and their applications in wheat breeding. Plant Breeding, 118: 369390.

Hasan MJ, Kulsum MU, Hossain E, Hossain MM, Rahman MM, Rahmat NMF (2015).Combining ability analysis for identifying elite parents for heterotic rice hybrids. Acad. J. Agric. Res. 3(5): 070-075.

Landry, B.S., R.Q. Li, W.Y. Cheung and R.L. Graner.(1994). Phylogeny analysis of 14 apple rootstocks using RAPD markers and tactical gene tagging.Theor. Appl. Genet., 89: 847852.

LathaSrikrishna, Deepak Sharma, Gulzar S. Sanghera (2013). Combining Ability and Heterosis for Grain Yield and its Component Traits in Rice (Oryza sativa L.), Not SciBiol, 5(1):90-97.

Neeraja, C.N., N. Sarla and E.A. Siddiq( 2002).RAPD analysis of genetic diversity in Indian landraces of rice (Oryza sativa L.). J. Plant Biochem. Biotechnol., 11: 93-97.

Panagal Mani, T.M.M. John Bastin, R. Arunkumar and Abdul Bakrudeen Ali Ahmed (2010).RAPD-ANALYSIS OF GENETIC VARIATION OF FOUR IMPORTANT RICE VARIETIES USING TWO OPR PRIMERS.ARPN Journal of Agricultural and Biological Science VOL. 5, NO. 4, 12-15.

Porreca, S.M.R., G. Martelli, F. Sunseri, I. Greco, G. Pruneddu and A. Spanu 
(2001).Genetic variability among Italian rice (Oryzasativs L.) cultivars investigated by RAPDs analysis. J.Genet. Breed., 55: 349-355.

Rabbani, M.A., M.S. Masood, Z.K. Shinwari and K. YamaguchiShinozaki.(2010). Genetic analysis of basmati and non-basmati Pakistani rice (Oryza sativa L.) cultivars using microsatellite markers. Pak. J. Bot.42: 2551-2564.

Rabbani, M.A., Z.H. Pervaiz and M.S. Masood. (2008). Genetic diversity analysis of traditional and improved cultivars of Pakistani rice ( OryzasativaL.) using RAPD markers.Elect. J. Biotechnol., 11: 1-10.

Raghunathachari, P., V.K. Khanna, U.S. Singh and N.K. Singh.(2000). RAPD analysis of genetic variability in Indian scented rice germplasm (OryzasativaL.).Curr. Sci., 79: 994-998. Rahman MA, Hasegawa H, Rahman MM, Islam MN, Miah MAM, Tasmen A (2007).Effect of arsenic on photosynthesis, growth and yield of five widely cultivated rice (Oryzasativa L.) varieties in Bangladesh. Chemosphere 67 1072-1079.

Raju Ch. Damodar, S. Sudheer Kumar, Ch. Surender Raju and A.Srijan (2014).Combining ability Studies in the Selected Parents and Hybrids in Rice (Oryza sativa .L), Int. J. Pure App. Biosci. 2 (4): 271-279.
Ren, F., B.R. Lu, S. Li, J. Huang and Y. Zhu.(2003). A comparative study of genetic relationships among the AAgenome Oryza species using RAPD and SSR markers.Theor. Appl. Genet., 108: 113-120.

Sambrook, J., Fritsch, K. F. and Maniatis, T., (1989).Molecular cloning, second edition (cold spring Harbor, New York).

Sasaki T (1999).Current status of and future prospects for genome analysis in rice. K. Shimamoto (eds.) "Moleclular Biology of Rice".Springer- Verlag pub., Tokyo. pp. 3-4.

Sasaki T (2002). Rice genomics to understand rice plant as an assembly of genetic codes. Current Sci. (83): 834839.

Weising $\mathrm{K}$, Atkinson $\mathrm{G}$, Gardner $\mathrm{C}$ (1995).Genomic fingerprinting by microsatellite-primed PCR: a critical evaluation. PCR Methods and Applications 4: 249-25.

Williams, J. K., Kubelik, A. R., Livak, K. J., Rafalski, J. A. and Tingey, S. V., (1990). DNA polymorphisms amplified by arbitrary primers are useful as genetic markers. Nucleic Acids Res., 18: 6531-6535.

Wyanne, J.C., D.A. Emery and P.W. Rice ( 1970). Combining ability estimates in Arachis hypogea L. II- Field Performance of F1 hybrids. Crop Sci. 10.

\section{How to cite this article:}

Heiba, S. A. A., A.A.El-Mouhamady, Sara E. I. Eldessouky, Hoda B. M. Ali and Elewa, T.A. 2016. Study the Genetic Variations Related to the Resistance of Heavy Metals Toxicity in Some Rice Genotypes Using RAPD Markers. 5(1): 174-189. doi: 'inttp://dx.doi.org/10.20546/ijcmas.2016.5011.015 